(C) Copyright by Wydawnictwa Naukowe Instytutu Lotnictwa

\title{
PROPULSION SYSTEM MODELLING FOR MULTI-SATELLITE MISSIONS PERFORMED BY NANOSATELLITES
}

\author{
Mateusz Sochacki, Janusz Narkiewicz \\ Department of Automation and Aeronautical Systems, Faculty of Power and Aeronautical Engineering \\ Warsaw University of Technology, ul. Nowowiejska 24 00-665 Warsaw \\ msochacki@meil.pw.edu.pl,jnark@meil.pw.edu.pl
}

Abstract

Progress in miniaturization of satellite components allows complex missions to be performed by small spacecraft. Growing interest in the small satellite sector has led to development of standards such as CubeSat, contributing to lower costs of satellite development and increasing their service competitiveness. Small satellites are seen now as a prospective replacement for conventional sized satellites in the future, providing also services for demanding users. New paradigms of multi-satellite missions such as fractionation and federalization also open up new prospects for applications of small platforms.

To perform a comprehensive simulation and analysis of future nanosatellite missions, an adequate propulsion system model must be used. Such model should account for propulsion solutions which can be implemented on nanosatellites and used in multi-satellite missions.

In the paper, concepts of distributed satellite systems (constellations, formations, fractionated and federated) are described with a survey of past, on-going and planned multi-satellite nanosatellites missions. Currently developed propulsion systems are discussed and the models of propulsion systems embedded in the WUT satellite simulation model are presented.

Keywords: propulsion, nanosatellite, formation flying, constellations, fractionated satellite, federated satellite systems

\section{INTRODUCTION}

Due to miniaturization of satellites subsystems, more complex missions are available even for small satellites. A small satellite is a spacecraft of mass lower than a few hundred kilograms (see Tab.1). 
Tab.1 Small satellite classification based on [1].

\begin{tabular}{|l|c|c|c|}
\hline Satellite class & Mass $(\mathrm{kg})$ & Cost $(\mathrm{M} €)$ & Development time (years) \\
\hline Mini & $100-1000$ & $7-100$ & $5-6$ \\
\hline Micro & $10-100$ & $1-7$ & $2-4$ \\
\hline Nano & $1-10$ & $0.1-1$ & $2-3$ \\
\hline Pico & $0.1-1$ & $<0.1$ & $1-2$ \\
\hline Femto & $<0.1$ & - & $1-2$ \\
\hline
\end{tabular}

Application of small platforms has several advantages, like low spacecraft and launching costs and short design and implementation cycle, which make small satellites perfect platforms for education and technology demonstrations. As more sophisticated payloads become applicable for small satellites, the interest in scientific and commercial application increases. Implementation of small platforms can be illustrated, for instance, by RapidEye and Flock Earth Observation (EO) constellations. Both of them acquire images of similar resolutions of $5 \mathrm{~m}$ per pixel and both occupy similar orbits. The first, however, is a $150 \mathrm{~kg}$ minisatellite, while the other is a $5 \mathrm{~kg}$ nanosatellite (and more precisely a $3 \mathrm{U}$ CubeSat) [2]. Another example of a small satellite constellation is the NASA's CYGNSS EO constellation with eight $25 \mathrm{~kg}$ microsatellites to perform measurements of wind speed over ocean surface and sea surface roughness using GNSS (Global Navigation Satellite System) signal reflectometry [3].

Several concepts of multi-satellite missions were considered in open literature, such as fractionated satellites [4,5] and federated systems [6]. As the use of small platforms allows for easy deployment of multiple satellites during one launch, it becomes apparent that they could be used to inexpensively verify new architectures.

As the interest in multi-satellite missions performed by nanosatellites increases, so does the need for comprehensive simulation and analysis. One of the key subsystems required in the simulation of a satellite is propulsion. An appropriate propulsion model should account for the technical solutions suitable for implementation on nanosatellites and capable of being used for satellite control during multi-satellite mission scenarios.

\section{DISTRIBUTED SATELLITE SYSTEMS}

The concept of Distributed Satellite System (DSS) has been considered for some time. It covers a variety of mission architectures involving more than one spacecraft cooperating in order to fulfil a common goal.

The oldest DSS incarnation is a constellation of satellites. Positions (or state vectors) of satellites in constellation are coordinated by an authority outside the fleet $[1,7]$, so there is also no need for information exchange between fleet members. Constellations are mainly used to provide specific spatial or temporal coverage. The most prominent example of satellite constellations are Global Navigation Satellite Systems.

Another DSS concept is satellite formation flying, in which (in contrast to constellation) satellites exchange information to maintain specified relative positions or attitudes, so the state vector of the formation flying satellite depends upon the state vectors of other satellites in the formation [1,7]. Satellite formations may be used to precisely position sensors mounted on separate flying platforms or to acquire coordinated measurements, for instance observe the same ground area in several time moments. 
Recently, formation flying has received more attention with renewed interest in the concept of fractionated spacecraft. Spacecraft fractionation is decomposition of functionalities of a single satellite between separate, free flying modules $[4,5]$ which communicate and interact with each other to deliver the capabilities of the previous single satellite. The main advantage of fractionated spacecraft is increased flexibility in maintenance and upgrading, but at the cost of increased complexity. Fractionation makes de-coupling of sensors possible, allowing to launch components separately, to add new subsystems or to replace malfunctioning components during an on-going mission. Fractionated spacecraft requires that some subsystems of various satellites be connected by data links. To manage fractionated spacecraft, it must be possible to determine and control the attitude and position of each fleet member. Some concepts assume that the modules could transmit power between each other or remotely exert forces [5]. The idea of spacecraft fractionation is illustrated in Pic. 1. It should be noted that to date, no fractionated spacecraft has been demonstrated.

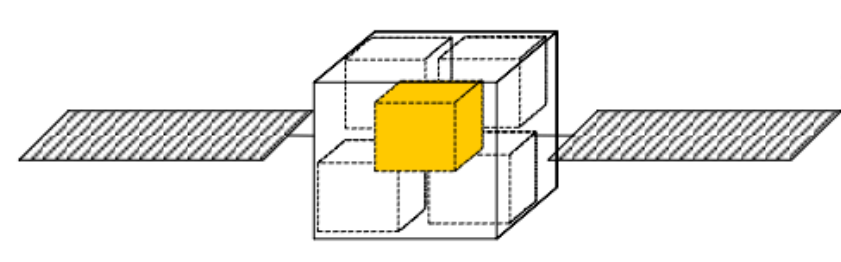

(1) Payload Module

(1) Bus Subsystems

a) Traditional Spacecraft

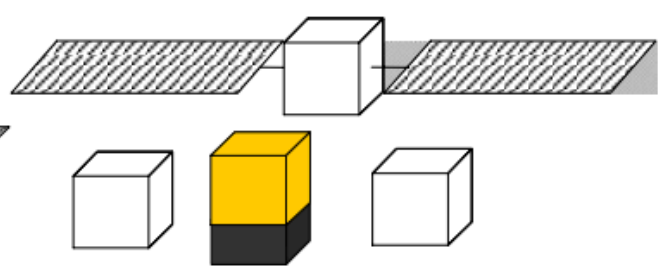

Gayload Module Infrastructure Modules

b) Fractionated Spacecraft

Pic. 1. Block diagram comparing traditional and fractionated spacecraft [8].

The newest DSS concept is the federated satellite system (FSS). FSS involves sharing the available resources between different satellite missions [6]. Similarly to spacecraft fractionation, FSS aims to increase system flexibility, but instead of decomposing a satellite into co-dependent modules, FSS covers multiple standalone missions connected through inter-satellite links (ISL). Each FSS satellite can perform a mission alone or utilize ISL to use other federated satellite resources to exchange data or perform measurements. The concept of FSS is often compared to the idea of cloud computing.

\section{MULTI-SATELLITE MISSIONS SURVEY}

A survey of past, currently operational, planed (with the launch date stated) and some conceptual Distributed Satellite Systems is presented below. The survey focused on missions of small satellites - mini size and smaller. It was originally performed in 2016 for the ONION project (H2020 Operational Network of Individual Observation Nodes) and is continuously updated. Now, the survey covers 92 missions, of which 49 are past or current. 
Satellite formation flying are $37 \%$ of the surveyed missions, constellations are $60 \%$ among which $20 \%$ use an inter-satellite link. Only $4 \%$ of the surveyed missions are related to fractionated spacecraft (all to be implemented in future) and only $7 \%$ are related to the concept of federalisation. The most popular platform (see Pic. 2) used in small multi-satellite missions is a nanosatellite (used in $71 \%$ of the missions). The use of platforms of various sizes is quite popular (12\% of the missions utilised platforms of multiple sizes).

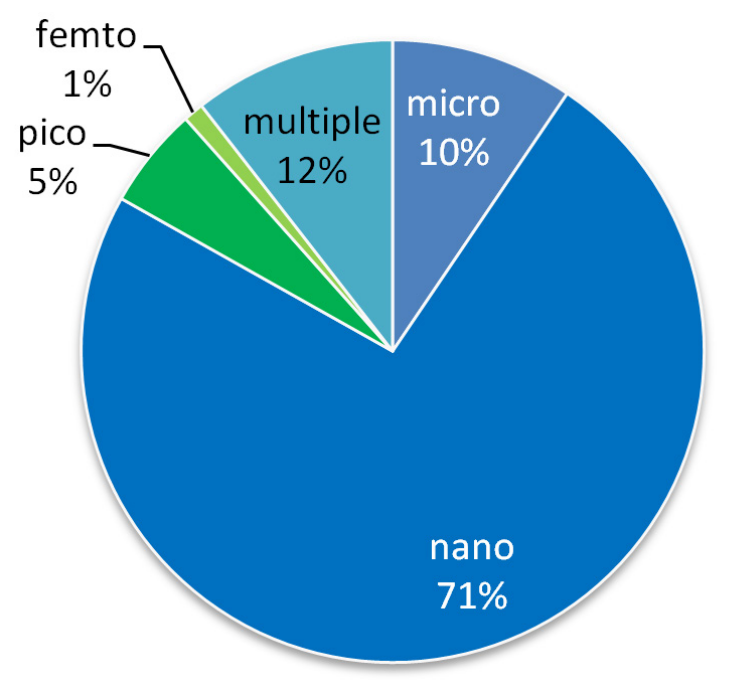

Pic. 2. Platforms used in the surveyed missions.

Nanosatellites are applied in the majority of multi-satellite missions. The Planet's Flock constellation is the largest satellite constellation ever built (currently it is composed of almost 200 operational satellites), the next in size is Iridium (constellation of over 90 large communicational satellites). Several Earth Observation (EO) constellations smaller than these are Spire's Lemur constellation (41 satellites at the time of writing this paper) and Astro Digital Landmapper constellation (currently with no operational satellites but aiming at 30 nano and microsatellites). The nanosatellite bus is the most popular size among all missions; there are also planned future constellations of tens or hundreds of satellites utilising a nanosatellite bus.

\subsection{Small satellites propulsion systems}

Most of the surveyed missions do not use active (excluding tethers) propulsion systems (see Pic. 3). They are members of non-controlled fleets or passively flying spacecraft in formation flying missions (i.e. the spacecraft around which other satellites manoeuvre). If applied on-board, propulsion systems are rarely used for attitude control as other devices (like reaction wheels and magnetorquers) are sufficient to perform this task and do not consume propellant.

The most popular propulsion systems among the surveyed missions use cold-gas ( $24 \%$ of the surveyed missions). Tether was used in $12 \%$ of the missions; although its role as propulsion may be questioned, in several surveys tethering is classified as propulsion for formation flying missions. Solid 
rocket propulsion is applicable for small satellites, but they were not identified within the survey. It may be explained by the fact that solid rocket propulsion is considered mainly for satellite deorbiting. No bipropellant applications were identified.

There are from $70 \%$ to $86 \%$ formation flying satellites equipped with propulsion (depending on how to count tethering, see Pic. 4). The rest of them were either tethered or passive fleet members, and for the rest of the fleet the most popular propulsion type was cold gas, as $49 \%$ of the formation flying satellites utilise it.

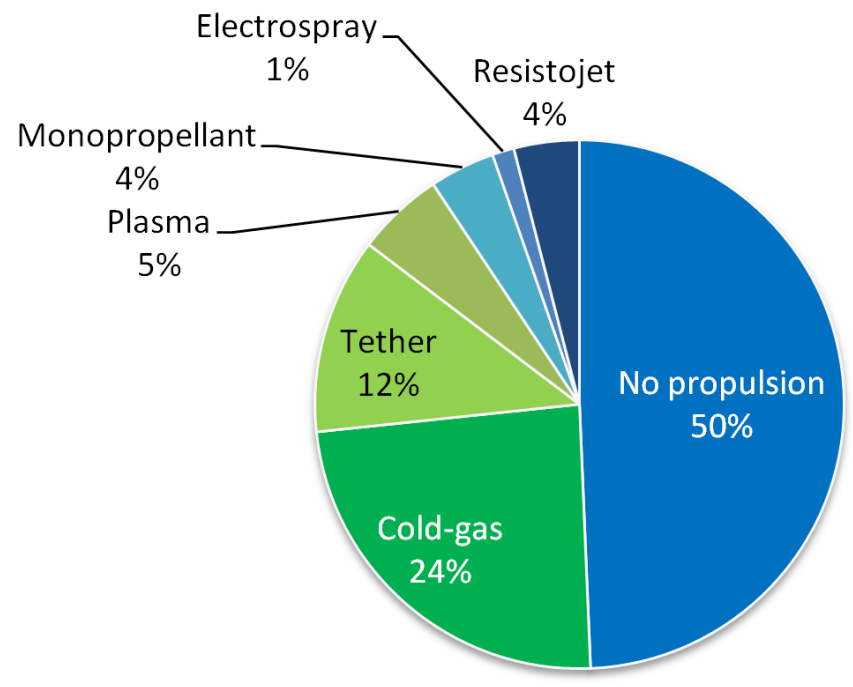

Pic. 3. Propulsion systems used in the surveyed multi-satellite missions.

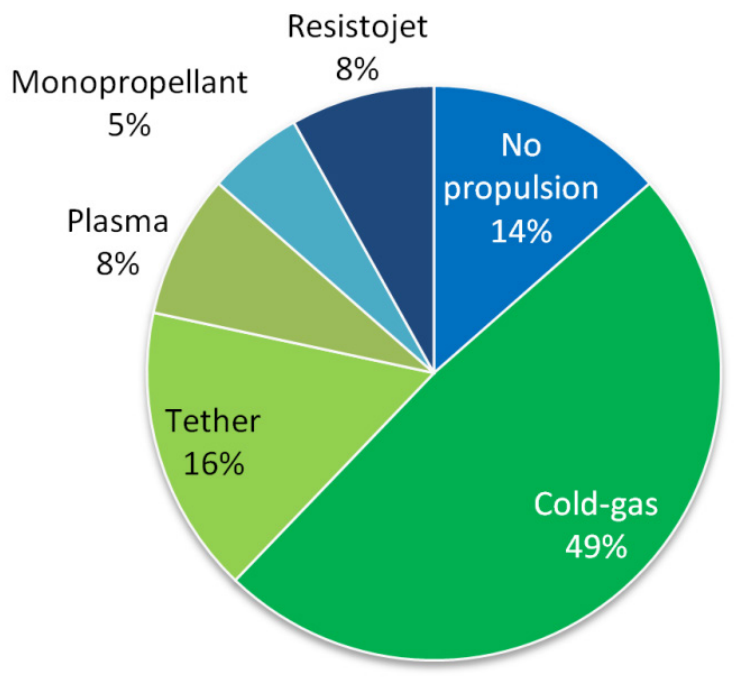

Pic. 4. Propulsion systems used on satellites involved in formation flying missions. 


\section{WUT SATELLITE SIMULATION MODEL}

The objective of the survey described above was to identify types of propulsion systems to be included into a satellite simulation model developed by the authors. Since 2016, the Warsaw University of Technology Satellite Simulation Model has been developed in order to create a tool for analysis of satellite motion and for development of navigation and control algorithms. The software is written in MatLab. A satellite is modelled as a six degrees of freedom rigid body, and rotational kinematics is described using the quaternion notation. The model contains inertia loads, a complete set of external loads (nonspherical gravity, aerodynamics, radiation pressure and control loads), models of sensors and actuators (reaction wheels, magnetorquers and thrusters), algorithms of control, guidance and navigation (Pic. 5).

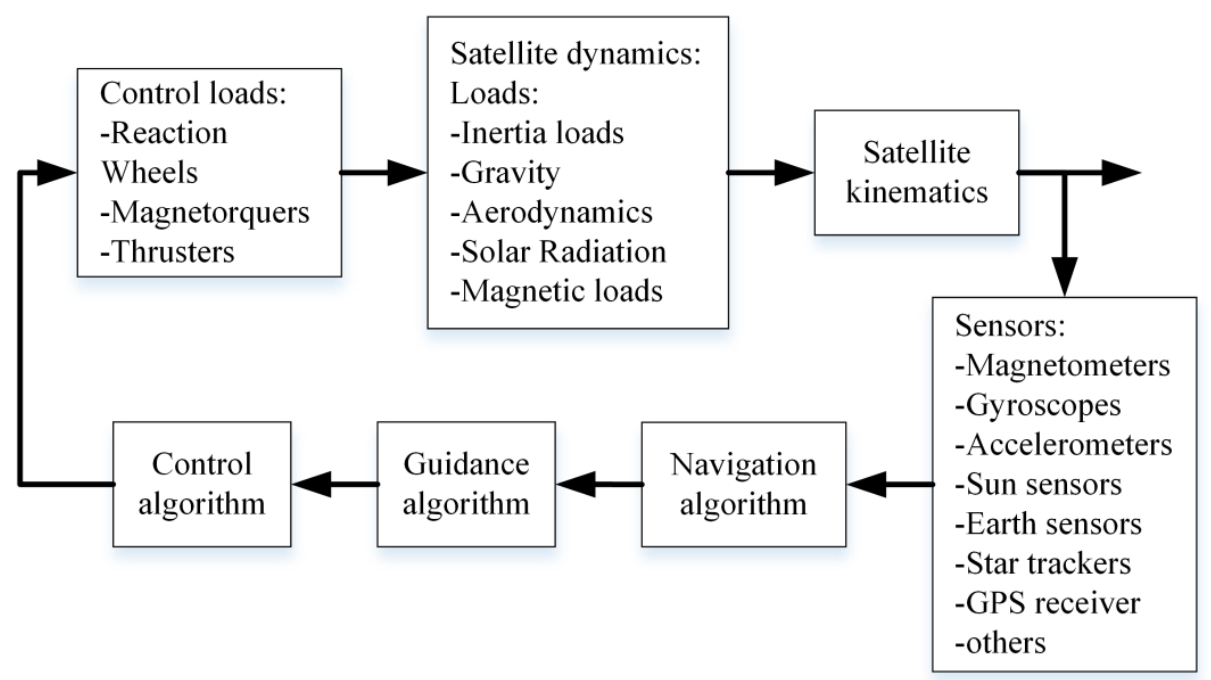

Pic. 5. Block diagram of the main loop of the WUT Satellite Simulation Model.

\subsection{Propulsion system modelling}

The requirements for the propulsion system model were: modular structure, ability to model various propulsion solutions (different types of thrusters). A propulsion system consumes propellant, which calls for a variable mass system, and the inertia variation depends on distribution of propellant tanks inside the bus. As a result, the propulsion system model is composed of two main model elements: thruster and propellant tank. Within the thruster model, the loads acting on the satellite and the mass flow rate of the propellant are calculated.

There may be a various number of thrusters and tanks applied in the bus. Each thruster generates loads (forces and moments) acting on a satellite in a specified location and direction (determined by the position and orientation of thrusters, see Pic. 6).

While generating loads, each thruster also generates mass flow which is distributed among various propellant tanks. In the actual version of the propulsion system model, to avoid simulation model complexity, each thruster has only one tank assigned, but this assignment can be changed during the simulation. If thrusters consumed propellant from several tanks, it would be necessary to design the distribution of mass flow between the tanks. 
The way propellant consumption influences satellite inertia depends on tanks positions in the bus. The tank model covers the influence of fuel consumption on satellite inertia by summing the mass flow rate from all assigned thrusters and calculating its influence on the total satellite inertia matrix. As each tank has a specified location and orientation (see Pic. 6), the satellite's inertia is influenced by the variation of propellant tanks inertia. The inertia properties represented by tank models correspond to the propellant stored within it, as the mass and moments of inertia of an empty tank are initially incorporated into satellite inertia properties.

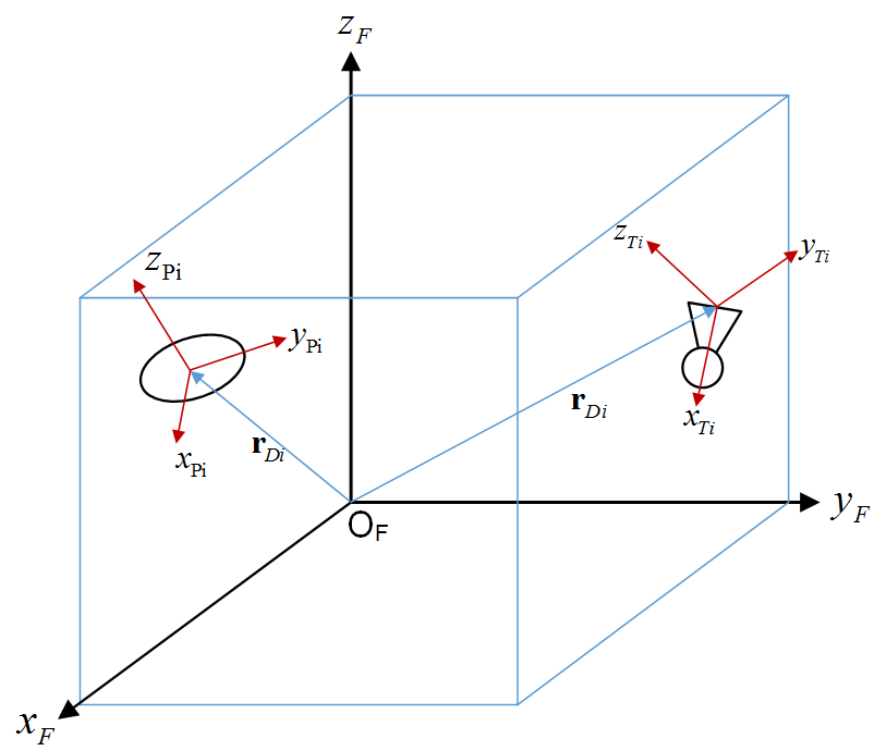

Pic. 6. Scheme of the satellite propulsion system model composed of a various number of thrusters and tanks.

The actual thrust generated by the $\mathrm{i}$-th thruster () is calculated as:

$$
t_{a i}=t_{n i} u_{T i}
$$

where: $\mathrm{t}_{\mathrm{ni}}-$ is $\mathrm{i}$-th thruster nominal thrust (scalar), $\mathrm{u}_{\mathrm{Ti}}-$ is $\mathrm{i}$-th thruster control input signal (value between 0 and 1 ).

For simplicity of description, in the case considered here the thrust acts along the thrusters axis but the model allows to accommodate off axial loads and torques, if relevant.

The nominal thrust is calculated using specific thruster characteristics. In the actual version of the simulation model, it is related to the pressure inside thrusters (operating pressure) by the formula:

$$
t_{n i}\left(p_{o i}\right)=C_{3}+C_{4} p_{o i}+C_{5} p_{o i}^{2}+C_{8} p_{o i}^{C_{9}}+C_{10} p_{o i}^{C_{11}}+C_{12}\left(C_{13}\right)^{C_{14} p_{o i}}
$$

where: $\mathrm{p}_{\mathrm{oi}}-$ is $\mathrm{i}$-th thruster operating pressure, $\mathrm{C}_{3}, \mathrm{C}_{4} \ldots, \mathrm{C}_{14}-$ are $\mathrm{i}$-th thruster thrust coefficients ("i" indices omitted for clarity). 
In Eq. 2 the relation of operating pressure to nominal trust was adopted from [9]. The coefficients $\mathrm{C}_{1}$ and $\mathrm{C}_{2}$ of the model related to the temperature of the propellant were neglected, as in the actual version of the model the thermodynamic properties of the propellant are not considered.

The operating pressure depends on the propellant pressure in a relevant propellant tank as:

$$
p_{o i}=\left\{\begin{array}{cl}
p_{\text {oimax }} & \text { if } p_{\text {oimax }} \leq p_{P i} \\
p_{P i} & \text { if } p_{\text {oimax }}>p_{P i}
\end{array}\right.
$$

where: $\mathrm{p}_{\mathrm{pi}}-$ is the propellant pressure in a tank used by $\mathrm{i}$-th thruster, $\mathrm{p}_{\mathrm{poimax}}-$ is the maximum operation pressure of $i$-th thruster.

When the pressure of propellant in a tank drops below minimal operating pressure $\mathrm{p}_{\text {poimin }}$ of the thruster, the thruster nominal thrust is assigned zero.

The $\mathrm{i}$-th thruster mass flow rate $\left(\dot{\mathrm{m}}_{\mathrm{ti}}\right)$ is calculated as:

$$
\dot{m}_{T i}=\frac{t_{a i}}{I_{s p i}}
$$

where $\mathrm{l}_{\mathrm{spi}}$ is the $\mathrm{i}$-th thruster specific impulse.

The specific impulse is calculated based on thruster characteristics. In the current model it is related to the operating pressure in a similar way to the nominal thrust as:

$$
I_{s p i}\left(p_{o i}\right)=K_{3}+K_{4} p_{o i}+K_{5} p_{o i}^{2}+K_{8} p_{o i}^{K_{9}}+K_{10} p_{o i}^{K_{11}}+K_{12}\left(K_{13}\right)^{K_{14} p_{o i}}
$$

where coefficients $\mathrm{K}_{3}, \mathrm{~K}_{4} \ldots, \mathrm{K}_{14}$ are thruster specific impulse coefficients (“i” indices omitted for clarity). Similarly to Eq.2, the coefficients $\mathrm{K}_{1}$ and $\mathrm{K}_{2}$ related to the temperature of the propellant were neglected.

The inertia properties of the tank are modelled as functions of time:

$$
\begin{gathered}
m_{P_{i}}=m_{P_{i}}(t) \\
I_{P_{i}}=I_{P_{i}}(t)
\end{gathered}
$$

where: $\dot{\mathrm{m}}_{\mathrm{pi}}-$ is the $\mathrm{i}$-th propellant tank mass, $\mathrm{I}_{\mathrm{Pi}}-$ is the $\mathrm{i}$-th propellant tank moments of inertia matrix.

The mass variation of $\mathrm{i}$-th tank is modelled by a differential equation:

$$
\frac{d}{d t} m_{P i}=-\sum_{j} \dot{m}_{T j}
$$

where $\dot{\mathrm{m}}_{\mathrm{Tj}}$ is the propellant mass flow rate to the $\mathrm{j}$-th thruster connected to this tank. The sign minus means that the propellant is depleted from the tank. 
The matrix of $\mathrm{i}$-th tank moments of inertia is calculated as a linear function of its mass:

$$
\boldsymbol{I}_{P i}\left(m_{P i}\right)=\boldsymbol{I}_{0 P i} \cdot \frac{m_{P i}}{m_{0 P i}}
$$

where: $\mathrm{I}_{0 \mathrm{Pi}}-$ is the $\mathrm{i}$-th tank initial moments of inertia matrix, $\mathrm{m}_{0 \mathrm{Pi}}-$ is the $\mathrm{i}$-th tank initial mass. This relation limits the applicability of the model to gaseous and some solid propellants.

Finally, the propellant pressure is calculated as:

$$
p_{P i}=k_{P i} \cdot m_{P_{i}}
$$

where the $\mathrm{k}_{\mathrm{pi}}$ is a constant (as it is assumed that the propellant has a constant temperature since there is no heat exchange modelled).

The developed propulsion system model allows to consider various designs of propulsion systems like solid rocket motors, electrical propulsion or thrusters utilising gaseous propellants. Due to the modular structure of the model, also other propulsion system designs (for instance, liquid propellant engines) may be easily included into the simulation environment. Although the general concept of calculating thrust using nominal thrust and specific impulse and their relations to operating pressure is based on [9], multiple modifications have been made. The model has been simplified in the sense that the influence of temperature has been neglected; however, it has also been expanded to allow for a full six degrees of freedom simulation. Each thruster and tank has a defined location and orientation interacting with the satellite thru forces, moments and inertia variations.

\section{CONCLUSIONS}

Although there are several commercial satellite simulation models available on the market (such as GMAT [9] or STK), they do not provide adequate flexibility of extension and modification required in the analysis of new multi-satellite mission architectures. This was the main rationale for developing an in-house satellite simulation model including the model of the propulsion subsystem. The developed model covers various propulsion technologies currently available for small satellites and accounts for the influence of all propulsion loads and inertia variations on satellite dynamics. The model was incorporated into the core simulation environment of the satellite simulation model and in the next step it will be used for orbital and attitude manoeuvres modelling. As a result, it will allow performance analysis of advanced on-board systems and especially, development of stabilization and control algorithms for satellites flying in formation.

\section{BIBLIOGRAPHY}

[1] Guerra, A. G. C., Francisco, F., Villate, J., Aguado Agelet, F., Bertolami, O., and Rajan, K., 2016, “On Small Satellites for Oceanography: A Survey," Acta Astronaut., 127, pp. 404-423.

[2] "Planet” [Online]. Available: https://www.planet.com. [Accessed: 15-Dec-2017].

[3] NASA, 2017, “Cyclone Global Navigation Satellite System (CYGNSS)” [Online]. Available: https:/www.nasa.gov/cygnss. [Accessed: 15-Dec-2017]. 
[4] Brown, O., and Eremenko, P., 2006, "Fractionated Space Architectures: A Vision for Responsive Space," $4^{\text {th }}$ Responsive Sp. Conf., p. RS4-2006-1002.

[5] Brown, O., and Eremenko, P., 2006, "The Value Proposition for Fractionated Space Architectures," AIAA SPACE 2006 Conference \& Exposition, pp. 1-22.

[6] Golkar, A. A., 2013, "Federated Satellite Systems (FSS): A Vision Towards an Innovation in Space Systems Design," IAA Symposium on Small Satellites for Earth Observation.

[7] Scharf, D. P., Hadaegh, F. Y., and Ploen, S. R., 2003, "A Survey of Spacecraft Formation Flying Guidance and Control (Part I): Guidance," Proc. 2003 Am. Control Conf., (Part I), pp. 1733-1739.

[8] Mathieu, C., and Weigel, a. L., 2005, "Assessing the Flexibility Provided by Fractionated Spacecraft," Collect. Tech. Pap. - AIAA Sp. 2005 Conf. Expo.

[9] NASA Goddard Space Flight Center, 2015, General Mission Analysis Tool (GMAT) Mathematical Specification.

\section{MODELOWANIE SYSTEMÓW NAPĘDOWYCH DLA WIELOSATELITARNYCH MISJI NANOSATELITÓW}

\section{Streszczenie}

Postępująca miniaturyzacja podzespołów satelitarnych pozwala na realizację skomplikowanych misji przez małe satelity. Wzrost zainteresowania małymi satelitami przyczynił się do powstania standardów takich jak CubeSat, umożliwiając zmniejszenie kosztów budowy oraz wzrost konkurencyjności usług oferowanych przez małe satelity. Istnieje przekonanie, że w najbliższym czasie małe satelity zastąpią satelity duże oferując usługi także wymagającym użytkownikom. Nowe architektury misji wielosatelitarnych jak federacyjne systemy satelitarne czy frakcjonowanie satelitów wskazują nowe możliwości wykorzystania małych satelitów.

Aby umożliwić zaawansowaną symulację i analizę nowych misji realizowanych przez nanosatelity konieczne jest wykorzystanie odpowiedniego modelu zespołu napędowego. Taki model powinien obejmować rozwiązania, które mogą zostać użyte na nanosatelitach do realizacji misji wielosatelitarnych.

W artykule opisano architektury misji (konstelacje, formacje, federacje i frakcjonowanie), a także przedstawiono przegląd zakończonych, trwających i planowanych misji wielosatelitarnych wykorzystujących nanosatelity. Omówione są obecnie wykorzystywane systemy napędowe oraz zaprezentowany jest model systemu napędowego wykorzystanego w modelu symulacyjnym satelity opracowanym przez zespół autorów.

Słowa kluczowe: napędy, nanosatelity, lot w formacji, konstelacje, frakcjonowanie satelitów, federacyjne systemy satelitarne. 